\title{
Effects of Liquid Yucca Supplementation on Nitrogen Excretion, Intestinal Bacteria, Biochemical and Performance Parameters in Broilers
}

\author{
Mousa M. Ayoub ${ }^{1}$, Hamada A. Ahmed ${ }^{2}$, Kadry M. Sadek ${ }^{3}$, Mahmoud Alagawany ${ }^{4, *(\mathbb{D} \text {, }}$ \\ Mohamed E. Abd El-Hack ${ }^{4}{ }^{\circledR}$, Sarah I. Othman ${ }^{5}$, Ahmed A. Allam ${ }^{6}$ and \\ Mervat A. Abdel-Latif $2, *$ (iD \\ 1 Department of Animal Hygiene and Zoonoses, Faculty of Veterinary Medicine Damanhour University, \\ Damanhour 22511, Egypt; mousa.ayoub@vetmed.dmu.edu.eg \\ 2 Department of Nutrition and Veterinary Clinical Nutrition, Faculty of Veterinary Medicine, \\ Damanhour University, Damanhour 22511, Egypt; hamada_nutrition@vetmed.dmu.edu.eg \\ 3 Department of Biochemistry, Faculty of Veterinary Medicine, Damanhour University, \\ Damanhour 22511, Egypt; kadry.sadek@vetmed.dmu.edu.eg \\ 4 Poultry Department, Faculty of Agriculture, Zagazig University, Zagazig 44511, Egypt; \\ dr.mohamed.e.abdalhaq@gmail.com \\ 5 Biology Department, College of Science, Princess Nourah bint Abdulrahman University, \\ Riyadh 11671, BO. Box 24428, Saudi Arabia; sialothman@pnu.edu.sa \\ 6 Department of Zoology, Faculty of Science, Beni-suef University, Beni-suef 65211, Egypt; \\ allam1081981@yahoo.com \\ * Correspondence: dr.mahmoud.alagwany@gmail.com (M.A.); \\ mervat.abdellatif@vetmed.dmu.edu.eg (M.A.A.-L.)
}

Received: 3 November 2019; Accepted: 6 December 2019; Published: 9 December 2019

check for updates

Simple Summary: Yucca schidigera had a positive effect on the improvement of economic traits, performance, and carcass characteristics of broilers. Saponin is the main steroidal chemical constituent of Yucca schidigera extract, which physically binds ammonia and reduces its level. Use of natural antibiotic alternatives such Yucca schidigera is necessary to improve growth rates and feed utilization, as well as decreasing nitrogen losses, feed cost, and global environmental pollution.

\begin{abstract}
This study was done to determine the impacts Yucca schidigera supplementation to drinking water on the excretion of nitrogen, and subsequently the level of ammonia, intestinal bacterial count, hematological and biochemical parameters, and some performance parameters. A total of 270 one-day old Cobb 500 chicks were equally divided into three groups ( 90 chicks/group). The first control group (G1) was fed on the basal diets without any yucca supplementation. The 2nd and 3rd groups (G2 and G3) were fed on basal diets with Yucca Plus liquid ${ }^{\circledR}$, at an 8 h/day supplementation rate of 0.5 , and $1 \mathrm{~mL} / \mathrm{L}$ to drinking water, respectively. The chicks that received yucca showed significant decreases in litter nitrogen content, when compared to controls. The chicks that received liquid yucca had reduced counts of total bacteria (TBC) $(p<0.05)$, Escherichia coli, and a non-significant increase in the number of lactic acid producing bacteria. They also showed increased activity of antioxidant enzymes, increased levels of immunoglobulins $M$ and $G$, and decreased levels of lipid peroxidation biomarkers, without a harmful effect on liver and kidney function. The chicks that received yucca showed a better feed conversion ratio. In conclusion, the use of natural additives is necessary to decrease nitrogen losses, feed cost, and environmental pollution; without adverse impacts on animal performance. Liquid supplementation of saponins is valuable for the performance, gut health, and welfare of broiler chickens.
\end{abstract}

Keywords: ammonia; broiler; intestinal bacteria; Yucca schidigera 


\section{Introduction}

It is well-known that the cost of feeding represents nearly $70 \%$ of the total production cost of broilers. The intensive breeding and high protein diet causes many environmental and intestinal hazards. For example, high aerial ammonia increases the incidence of enteric diseases. Higher concentrations of gaseous $\mathrm{NH}_{3}$ is the most predominant pollutant in poultry farms, which adversely affects performance, the welfare of birds, and consequently, human health [1]. In addition, high levels of ammonia may reduce feed intake and deteriorate the growth rate of birds due to damage to the respiratory tract, increasing their susceptibility to Newcastle disease virus, the incidence of air sacculitis and kerato conjunctivitis, in addition to the already high prevalence of Mycoplasma gallisepticum [2]. Decreasing nitrogen emissions in poultry houses is important to keep both birds and humans healthy [3]. About 70\% of nitrogenous substances in excrement originate from urine, and $30 \%$ from feces. Poultry excreta contains about $60-65 \%$ uric acid, $10 \%$ ammonium salts, $2-3 \%$ urea. Remaining creatinine, and especially uric acid, is rapidly changed to $\mathrm{NH}_{3}$ by microbes [4].

Several chemicals and treatments have been adopted to control ammonia emissions in poultry houses such as zeolites, aluminum chloride, and supplementation of Yucca schidigera extract in poultry feed [5-7]; these compounds also improve metabolic efficiency, egg weight, feed conversion, and production traits [8-11].

Yucca schidigera is a widespread herbal plant with different beneficial activities, such as growth stimulation and immunostimulation, as well as antioxidant, anti-inflammatory, anticarcinogenic effects, and hypoglycemic and hypocholesterolemic activities [12]. Y. schidigera plays a key role in mitigating ammonia emissions and fecal odors emanating from poultry houses and surrounding areas [13]. Furthermore, the extract and powder of $Y$. schidigera are abundant in steroidal saponins, and are used as feed supplements and cosmetic [14]. Yucca schidigera is a commercially important source of various enzymes, saponins, antioxidants, and resveratrol [7]. Saponin is the main steroidal chemical constituent of $Y$. schidigera extract, which physically binds ammonia and reduces its level. Its extract contains a glycol-fraction, which has ammonia binding capabilities, and a saponin fraction, which has antiprotozoal and antimicrobial properties. Yucca schidigera has a positive effect on the improvement of economic traits, performance, and carcass characteristics of broilers and quails $[15,16]$. The health status of the intestinal tract shows a significant improvement, and the growth of pathogenic bacteria was reduced as a result of Yucca schidigera administration [17]. Therefore, the aim of this study was to evaluate the effect of adding Yucca schidigera to the drinking water of broiler chickens on reducing the atmospheric ammonia levels, and minimizing litter nitrogen. Also, the study aimed to assess its effects on intestinal bacterial flora, biochemistry, and other performance parameters.

\section{Materials and Methods}

All procedures and experiments were performed in accordance with the Ethics of the Committee of Local Experimental Animal Care, and were approved by the Nutrition and Veterinary Clinical Nutrition Institutional Committee, Faculty of Veterinary Medicine, Damanhour University, Damanhour, Egypt (DMU2018-0045). All efforts were made to minimize animal suffering.

\subsection{Birds, Housing and Vaccinations}

A total of 270 one-day old (DO), commercial, unsexed Cobb 500 chicks, obtained from a local commercial hatchery were equally divided into three groups ( 90 chicks/group; each group had six replicates each of 15 chicks). Birds were raised on deep litter and received experimental diets for five consecutive weeks. The ambient temperature was maintained at $32{ }^{\circ} \mathrm{C}$ in the first week, and gradually decreased $\left(3{ }^{\circ} \mathrm{C} /\right.$ week $)$ to $21^{\circ} \mathrm{C}$ on the 5 th week. Chicks were exposed to continuous light during the first two days of age, and then exposed to light for $23 \mathrm{~h}$, followed by an hour of darkness per day thereafter. Diets and fresh water were supplied ad libitum. 


\subsection{Diets and Experimental Design}

The chicks were fed on starter diet during the first three weeks ( 0 to 21 days) and finisher diet during the second two weeks (22 to 35 days), to meet the recommendation of the National Research Council [18] for broilers. The diets were chemically analyzed as shown in Table 1. The first control group (G1) was fed on the basal diet without any yucca supplementation in water, while the 2nd and 3rd groups (G2 and G3) were fed on basal diets with yucca supplementation (Yucca Plus liquid ${ }^{\circledR}$, Beijing Xiqin Pharmaceutical Co., Ltd., Beijing, China), at an $8 \mathrm{~h} /$ day supplementation rate of 0.5 , and $1 \mathrm{~mL} / \mathrm{L}$ to drinking water, respectively.

Table 1. Ingredient composition of the experimental basal diets.

\begin{tabular}{|c|c|c|}
\hline Ingredients & Starter $(0-21)$ & Finisher (22-35) \\
\hline Yellow Corn & 55.60 & 68.36 \\
\hline Soybean meal, $46 \%$ & 36.1 & 21.5 \\
\hline Full-fat soya bean & 4.5 & 7 \\
\hline DL-Methionine & 2.4 & 1.5 \\
\hline L-Lysine & 1.6 & 1.4 \\
\hline Mono-calcium phosphate & 1 & 0.75 \\
\hline Calcium carbonate & 1.7 & 1.4 \\
\hline Sodium chloride & 0.27 & 0.27 \\
\hline Vitamin and mineral premix * & 0.3 & 0.3 \\
\hline Choline chloride & 0.05 & 0.05 \\
\hline Physical anti-mycotoxin & 0.05 & 0.05 \\
\hline Anticoccidials & 0.05 & 0.05 \\
\hline Biological anti-mycotoxin & 0.025 & 0.025 \\
\hline \multicolumn{3}{|l|}{ Analyzed and calculated composition (\%) } \\
\hline Metabolizable energy (ME) kcal/kg diet & 3010 & 3175 \\
\hline Crude protein $(\mathrm{CP})$ & 22.4 & 18 \\
\hline Ether extract (EE) & 3 & 4.3 \\
\hline Crude fiber $(\mathrm{CF})$ & 2.18 & 2.8 \\
\hline Calcium (Ca) & 1.04 & 0.85 \\
\hline Available Phosphorous & 0.51 & 0.46 \\
\hline Linoleic acid & 1.5 & 2 \\
\hline Methionine & 0.58 & 0.45 \\
\hline Methionine + Cysteine & 0.98 & 0.79 \\
\hline Lysine & 1.44 & 1.1 \\
\hline Sodium $(\mathrm{Na})$ & 0.2 & 0.2 \\
\hline Chloride $(\mathrm{Cl})$ & 0.27 & 0.26 \\
\hline
\end{tabular}

* Each $2 \mathrm{~kg}$ of vitamin mineral premix contains: vitamin A, 1,200,000 IU; vitamin $\mathrm{D}_{3}, 300,000 \mathrm{IU}$; vitamin $\mathrm{E}, 700 \mathrm{mg}$; vitamin $K_{3}, 500 \mathrm{mg}$; vitamin $B_{1}, 500 \mathrm{mg}$; vitamin $B_{2}, 200 \mathrm{mg}$; vitamin $B_{6}, 600 \mathrm{mg}$; vitamin $B_{12}, 3 \mathrm{mg}$; folic acid, $300 \mathrm{mg}$; choline chloride, $1000 \mathrm{mg}$; Niacin, $3000 \mathrm{mg}$; Methionine, $3000 \mathrm{mg}$; Biotin, $6 \mathrm{mg}$; panathonic acid, $670 \mathrm{mg}$; manganese sulphate, $3000 \mathrm{mg}$; iron sulphate, $10,000 \mathrm{mg}$; zinc sulphate, $1800 \mathrm{mg}$; copper sulphate, $3000 \mathrm{mg}$; iodine, $1.868 \mathrm{mg}$; cobalt sulphate, $300 \mathrm{mg}$; and selenium, $0.108 \mathrm{mg}$.

\subsection{Performance Parameters}

The initial body weight (iBW), final body weight (fBW), feed intake (FI), and body weight gain (BWG) were recorded. Whereas, the feed conversion ratio (FCR) and protein efficiency ratio (PER) were calculated.

\subsection{Litter Sampling and Analysis}

The litter was sampled on the 21st and 35th days from each poultry pen. Samples from 10 random locations (avoiding areas around feeders and drinkers) were collected. Subsequently, the random litter samples were thoroughly mixed in a plastic bag, and $250 \mathrm{~g}$ was weighed and delivered for further processing in the laboratory. The sample was ground to pass through a $2 \mathrm{~mm}$ sieve, and frozen until further analysis. Dry matter (DM) of the litter was determined by oven-drying at $105{ }^{\circ} \mathrm{C}$ for $48 \mathrm{~h}$, and 
calculating the differences in weight. Ash contents of litter samples were determined by incineration at $550{ }^{\circ} \mathrm{C}$ overnight. Nitrogen in the litter samples was determined by using the Kjeldahl method, according to Association of Official Analytical Chemists (AOAC) [19] (method 988.05).

\subsection{Evaluation of Intestinal Bacterial Flora}

At 10, 18 and 28 days of age, thirty six birds were randomly selected and slaughtered. In order to evaluate the effect of yucca supplementation at different concentrations to drinking water on the colonization of pathogenic and beneficial bacteria in comparison to the control group, a total of 36 cecal samples were collected from all chickens, throughout the experimental period (12 samples/group). Cecum content weighing $1 \mathrm{~g}$ was removed from the birds. To determine the colony forming units (CFU), one gram of the cecum content in the vicinity of a hot flame was added to $9 \mathrm{~mL}$ of peptone water (tube number one), and the solution was shaken. Then, $1 \mathrm{~mL}$ of solution was added to the next tube (tube number two), by a sampler containing $9 \mathrm{~mL}$ of sterile peptone water. This operation was conducted serially until tube number eight, and a dilution series was prepared according to Mountzouris et al. [20]. The samples were placed on a plate containing eosin methylene blue agar, MacConkey agar, and Rogasa medium for the growth of Escherichia coli, coliforms, and lactic acid bacteria. However, nutrient agar medium was prepared for the counting of the total cultured bacteria. This process was repeated for each sample. MacConkey, eosin methylene blue, and nutrient agar, as well as Rogasa media, were incubated at $37^{\circ} \mathrm{C}$ for $24 \mathrm{~h}$. Finally, the samples were evaluated when they reached between 25 and 300 colonies, which were selected at an appropriate dilution. After counting, the number of colonies was multiplied by the inverse of the dilution to obtain the number of bacteria.

\subsection{Biochemical Parameters}

At the third and the fifth weeks of age, six birds from each group were randomly selected and fasted overnight, blood samples were then collected through slaughtering into non-heparinized chilled tubes, followed by centrifugation at $3500 \mathrm{rpm}$ for $15 \mathrm{~min}$ at $4{ }^{\circ} \mathrm{C}$. The separated sera was kept at $-20^{\circ} \mathrm{C}$ for biochemical investigation. Lipid peroxidation (LPO), assessed as the generation of thiobarbituric acid-reactive substances (TBARS) [21]; glutathione (GSH), assessed by Ellman's reagent [22]; catalase (CAT) (EC 1.11.1.6) activity, determined as the rate of hydrolysis of $\mathrm{H}_{2} \mathrm{O}_{2}$. The superoxide dismutase (SOD) activity was determined as the sample was reacted with an adrenaline solution, and the degree of prevention of adenochrome synthesis from auto-oxidation was assessed at $480 \mathrm{~nm}$ [23]. The activities of the serum alanine amino transferase (ALT), and levels of serum proteins, globulin, albumin, and creatinine were spectrophotometrically determined using industrially available kits (Biodiagnostic Co., Dokki-Giza, Egypt), following the manufacturer's instructions. Serum immunoglobulins (IgG and IgM) were determined using commercial ELISA kits (Kamiya Biomedical Company, Tukwila, WA, USA), according to Bianchi et al. [24]. Triglycerides and total cholesterol were determined according to Fossati Prencipe [25], and Stein [26], respectively.

\subsection{Statistical Analysis}

The obtained data were subjected to an Analysis of Variance (ANOVA) test, appropriate for a completely randomized design, using the statistical program SPSS.20 ${ }^{\circledR}$ (IBM Cooperation, Armonk, NY, USA) to assess the significant differences with a Tukey's range test. Statements of statistical significance were based on $p<0.05$.

\section{Results}

\subsection{Performance Measurements}

Results concerning the effect of yucca supplementation at two levels $(0.5$ and $1 \mathrm{~mL} / \mathrm{L}$ of drinking water) on broiler performance are shown in Table 2. There was a numerical increase in final body weight in the groups treated with yucca, when compared to the control group. Concerning total 
body weight gain, the experimental groups supplemented with 0.5 and $1 \mathrm{~mL} / \mathrm{L}$ showed a 1.65 and $2.32 \%$ increase, relative to control increase in weight gain. Table 2 shows the significant difference in total feed intake in groups with yucca supplementation. There was significant improvement in feed conversion ratio, and protein efficiency in the yucca supplemented group at level $0.5 \mathrm{~mL} / \mathrm{L}$ drinking water, compared to the control one.

Table 2. Effect of dietary yucca supplementation on performance parameters of broiler chickens.

\begin{tabular}{ccccc}
\hline \multirow{2}{*}{ Parameter } & \multicolumn{3}{c}{ Group $^{\mathbf{1}}$} & \multirow{2}{*}{$\boldsymbol{p}$-Value ${ }^{2}$} \\
\cline { 2 - 4 } & G1 & G2 & G3 & \\
\hline Body weight (iBW, g) & $174.46 \pm 2.26$ & $173.04 \pm 2.31$ & $173.15 \pm 2.23$ & 0.887 \\
Final body weight (fBW, g) & $1832.28 \pm 26.21$ & $1857.07 \pm 34.13$ & $1869.46 \pm 28.56$ & 0.669 \\
Body weight gain (BWG, g) & $1657.83 \pm 23.99$ & $1684.02 \pm 31.87$ & $1696.3 \pm 26.37$ & 0.604 \\
Total feed intake (TFI, g) & $3172^{\mathrm{a}} \pm 15.72$ & $3166.5^{\mathrm{b}} \pm 23.98$ & $2809.3^{\mathrm{c}} \pm 18.95$ & 0.005 \\
Feed conversion ratio (FCR) & $1.93 \pm 0.02^{\mathrm{a}}$ & $1.91 \pm 0.04^{\mathrm{a}}$ & $1.67 \pm 0.03^{\mathrm{b}}$ & 0.05 \\
Protein efficiency ratio (PER) & $2.41 \pm 0.05^{\mathrm{b}}$ & $2.44 \pm 0.05^{\mathrm{b}}$ & $2.88 \pm 0.05^{\mathrm{a}}$ & 0.05 \\
\hline
\end{tabular}

${ }^{\mathrm{a}-\mathrm{c}}$ Means within the same row that carry different superscripts are significantly different at $p<0.05 .{ }^{1} \mathrm{G} 1$ : control without supplementation, G2: $0.5 \mathrm{~mL} / \mathrm{L}, 8 \mathrm{~h} /$ day drinking water and G3: $1 \mathrm{~mL} / \mathrm{L}, 8 \mathrm{~h} /$ day drinking water, Mean $\pm \mathrm{SE}$.

${ }^{2}$ Overall treatment $p$-value.

\subsection{Nitrogen, Moisture and Ash Content of the Litter}

Effect of yucca supplementation on different groups on litter nitrogen \%, is shown in Table 3. At the 21st day, groups which were supplemented with yucca showed significant decreases in nitrogen content compared to untreated one $\left(0.72 \pm 0.023^{b}\right.$ and $0.52 \pm 0.023^{c}$, vs. $\left.0.813 \pm 0.013^{a}\right)$ for 0.5 and $1 \mathrm{~mL} / \mathrm{L}$ vs. control. In the same manner, litter samples of groups supplemented with yucca at levels of 0.5 and $1 \mathrm{~mL} / \mathrm{L}$ at the 35th day showed significant decreases in nitrogen content comparing to the control. Groups supplemented with yucca at levels of 0.5 and $1 \mathrm{~mL} / \mathrm{L}$ at the 35 th day showed a lower nitrogen content by about 60 and $46.67 \%$, compared to the control. Concerning the effect of yucca supplementation on litter moisture content, during the 3rd and the 5th weeks, yucca supplemented groups showed significant decreases in moisture content, compared to the control group.

Table 3. Effect of liquid yucca supplementation on litter content of nitrogen, moisture, and ash.

\begin{tabular}{ccccc}
\hline Parameter & \multicolumn{3}{c}{ Group $^{\mathbf{1}}$} & \multirow{2}{*}{$\boldsymbol{p}$-Value ${ }^{2}$} \\
\cline { 2 - 4 } & G1 & G2 & G3 & \\
\hline Nitrogen (\%) & & & & \\
Day 21 & $0.813 \pm 0.013^{\mathrm{a}}$ & $0.72 \pm 0.023^{\mathrm{b}}$ & $0.52 \pm 0.023^{\mathrm{c}}$ & 0.005 \\
Day 35 & $1.20 \pm 0.046^{\mathrm{a}}$ & $0.72 \pm 0.046^{\mathrm{b}}$ & $0.56 \pm 0.023^{\mathrm{c}}$ & 0.005 \\
Moisture (\%) & & & \\
Day 21 & $33.50 \pm 0.12^{\mathrm{a}}$ & $31.97 \pm 0.15^{\mathrm{b}}$ & $30.70 \pm 0.06^{\mathrm{c}}$ & 0.005 \\
Day 35 & $32.97 \pm 0.15^{\mathrm{a}}$ & $30.77 \pm 0.15^{\mathrm{b}}$ & $29.97 \pm 0.20^{\mathrm{c}}$ & 0.005 \\
Ash (\%) & & & & \\
Day 21 & $22.80 \pm 0.12^{\mathrm{a}}$ & $22.23 \pm 0.15^{\mathrm{b}}$ & $22.17 \pm 0.17^{\mathrm{b}}$ & 0.039 \\
Day 35 & $21.33 \pm 0.20^{\mathrm{a}}$ & $20.43 \pm 0.22^{\mathrm{b}}$ & $20.30 \pm 0.15^{\mathrm{b}}$ & 0.018 \\
\hline
\end{tabular}

a-c Means within the same row that carry different superscripts are significantly different at $p<0.05 .{ }^{1}$ G1: control without supplementation, G2: $0.5 \mathrm{~mL} / \mathrm{L}, 8 \mathrm{~h} /$ day drinking water, and G3: $1 \mathrm{~mL} / \mathrm{L}, 8 \mathrm{~h} /$ day drinking water, Mean \pm $\mathrm{SE}^{2}$ Overall treatment $p$-value.

\subsection{Evaluation of Intestinal Bacterial Count}

The results in Table 4 show that ceacal samples taken at 10 days of age had a significant decrease in total colony counts $(p<0.05)$ in the group that received yucca at rate of $1 \mathrm{~mL} / \mathrm{L}$, as compared to the control group, and a non-significant decrease in the group receiving $0.5 \mathrm{~mL}$ yucca/L. Also, a significant decrease in the count of E. coli $(p<0.05)$ in both yucca groups was detected, compared to the control group. In addition, no significant change in the count of lactic acid producing bacteria $(p>0.05)$ in 
either yucca group was recorded. At 18 days of age, a numerical decrease in the total colony count $(p>0.05)$ in the two yucca groups was found. Supplementing yucca to the drinking water also led to a significant decrease in $E$. coli numbers $(p<0.05)$. However, the number of lactic acid producing bacteria was not affected.

Table 4. Effect of dietary yucca supplementation on the count of intestinal bacteria (total colony count (TCC), E. coli and Lactic acid producing bacteria (L.A.B.).

\begin{tabular}{ccccc}
\hline & \multicolumn{3}{c}{ Group $^{\mathbf{1}}$} & \\
\cline { 2 - 4 } Parameter & G1 & G2 & G3 & \\
\cline { 2 - 4 } Day 10 & & & & \\
TCC $\times 10^{9}$ & $7.4 \pm 0.32^{\mathrm{a}}$ & $6.5 \pm 0.39^{\mathrm{a}} \mathrm{b}$ b & $6.3 \pm 0.40^{\mathrm{b}}$ & 0.018 \\
E. coli $\times 10^{7}$ & $8.2 \pm 0.43^{\mathrm{a}}$ & $6.3 \pm 0.36^{\mathrm{b}}$ & $6.1 \pm 0.37^{\mathrm{b}}$ & 0.017 \\
L.A.B. $\times 10^{8}$ & $1.4 \pm 0.23$ & $1.9 \pm 0.19$ & $1.8 \pm 0.23$ & 0.751 \\
Day 18 & & & & \\
TCC $\times 10^{9}$ & $6.4 \pm 0.44$ & $6.1 \pm 0.33$ & $6.0 \pm 0.35$ & 0.597 \\
E. coli $\times 10^{7}$ & $2.5 \pm 0.28^{\mathrm{a}}$ & $1.0 \pm 0.08^{\mathrm{b}}$ & $1.2 \pm 0.13^{\mathrm{b}}$ & 0.016 \\
L.A.B. $\times 10^{8}$ & $4.2 \pm 0.47$ & $5.1 \pm 0.38$ & $4.5 \pm 0.35$ & 0.743 \\
Day 28 & & & & \\
TCC $\times 10^{9}$ & $6.0 \pm 0.37^{\mathrm{a}}$ & $4.0 \pm 0.33^{\mathrm{b}}$ & $6.0 \pm 0.28^{\mathrm{a}}$ & 0.015 \\
E. coli $\times 10^{7}$ & $4.4 \pm 0.39$ & $3.5 \pm 0.30$ & $4.0 \pm 0.32$ & 0.653 \\
L.A.B. $\times 10^{8}$ & $4.0 \pm 0.32$ & $4.5 \pm 0.34$ & $4.2 \pm 0.47$ & 0.721 \\
\hline
\end{tabular}

$\mathrm{a}, \mathrm{b}$ Means within the same row that carry different superscripts are significantly different at $p<0.05 .{ }^{1} \mathrm{G} 1$ : control without supplementation, G2: $0.5 \mathrm{~mL} / \mathrm{L}, 8 \mathrm{~h} /$ day drinking water, and G3: $1 \mathrm{~mL} / \mathrm{L}, 8 \mathrm{~h} /$ day drinking water, Mean $\pm \mathrm{SE}$.

2 Overall treatment $p$-value. TCC, total colony count; LAB, lactic acid bacteria.

At 28 days of age, the total colony count was insignificantly decreased in the group receiving $0.5 \mathrm{~mL}$ yucca/L, as compared to the control group. Furthermore, supplementing yucca insignificantly depressed the number of E. coli $(p>0.05)$ and lactic acid producing bacteria $(p>0.05)$ in both yucca groups, in comparison to the control group.

\subsection{Biochemical Parameters}

The results revealed that the addition of yucca significantly $(p<0.05)$ increased the activity of antioxidant enzymes (SOD and GSH), and decreased the level of malondialdehyde (MDA) (a lipid peroxidation biomarker), compared to the control group at the end of the study. In addition, serum globulin and IgM were insignificantly higher in yucca supplemented groups than that of the control group on the 21st and 35th days of age. However, IgG was lower in G3 compared to G1 and G2 $(p=0.001)$. On the other hand, kidney and liver function biomarkers were not affected.

\section{Discussions}

Our results concerning growth performance, agree with that of Cabuk et al. [27], who found a numerical increase in the body weight of broilers fed a diet supplemented with Yucca schidigera, compared to a control group. This may be related to the positive effects of steroid saponin present in yucca on nutrient absorption. Previous research has demonstrated that saponin can improve the absorption of nutrients from the intestinal tract [28]. These results are supported by those of Su et al. [29], who found that dietary supplementation of $Y$. schidigera powder at a level of $100 \mathrm{ppm}$ improved body weight gain and feed efficiency during the finisher period. In line with these results, Sahoo et al. [30] found that yucca supplementation could effectively lead to a better feed conversion rate and protein efficiency ratio, than in an un-supplemented group. The improvement of FCR and PER in the yucca supplemented groups may be attributed to the presence of natural saponin from Y. schidigera, which might result in the emulsification of oil fats, promoting their digestion, and the absorption of vitamins and minerals [31]. 
In poultry, about $60-70 \%$ of the excreted nitrogen is in the form of uric acid, which starts to be converted into urea as soon as urine comes into contact with feces, by the action of urease. The conversion rate of urea into ammonia is temperature dependent, and is greatly decreased at temperatures below $5-10^{\circ} \mathrm{C}$ [32]. This result confirms that Yucca Plus liquid ${ }^{\circledR}$ added to drinking water can enhance the absorption of nitrogen and reduce its excretion, and therefore reduce the level of ammonia in the animal's digestive tract and excreta [33]. This reduces the level of ammonia in the poultry houses, which is detrimental to the performance of modern commercial broilers [34]. Moreover, low percentages of nitrogen and moisture have been found in the yucca treated groups, compared to the control one [30]. This may be due to the amount of saponin in yucca, which has surfactant properties, is enough to increase nutrient absorption [10,35-38]. Also, yucca is used as an $\mathrm{NH}_{3}$ inhibitor, which can improve the air quality around the birds and improves their performance [5]. Also, our results agree with those of Cheeke [39], who concluded that $Y$. schidigera extracts were capable of binding $\mathrm{NH}_{3}$ directly, thus decreasing its production in animal houses. Similarly, the addition of yucca at $100 \mathrm{ppm}$ has been shown, in comparison with the other levels $(0,50,100$, and $200 \mathrm{ppm})$, to significantly reduce emissions $(p<0.05)$ of $\mathrm{NH}_{3}$ by 44 and $28 \%$ on the 1 st and 2 nd days of manure storage, respectively [40]. Also, Hussain et al. [41] reported that extracts of yucca have ammonia-binding properties. It was hypothesized that by binding ammonia in the caecum, yucca could affect utilization of crude protein and dietary urea in ceca. The impact of yucca extract supplementation is manifested in mitigating levels of ammonia in the caecum of animals [42].

The results in Table 4 indicated that the addition of yucca to the broiler drinking water is of value in reducing total bacterial count and the number of E. coli in different ages, especially in the young age. Wang and Kim [28] found that E. coli counts were linearly inhibited by Yucca schidigera extract treatments, compared with the non-treated group at both five and eight weeks, and no difference was observed on the Lactobacillus population throughout the experimental period.

The result of ALT and creatinine revealed that yucca had no adverse effect on liver and kidney functions. Also, the levels of IgM and G revealed that yucca had an immunostimulant effect in broilers. Similar findings were obtained by Su et al. [29], who found that dietary supplementation of $100 \mathrm{ppm}$ Y. schidigera powder increased IgG, and induced IgM. At a level of $200 \mathrm{ppm}$, a better effect on cellular and humoral immune responses in broilers was seen. Our results showed an adjustment effect of yucca extract on the humoral and cellular immune responses.

Regarding antioxidative biomarkers, results in Table 5 confirmed that the addition of yucca improved the activity of antioxidant enzymes including SOD, CAT, and GSH, and decreased lipid peroxidation biomarkers compared to the control group. Similarly, Su et al. [29] demonstrated that broiler chickens fed yucca showed a significant improvement in SOD activity, and exhibited a strong antioxidative effect. Yucca is a good source of many phytochemicals like resveratrol and other bioactive components, such as yuccaols (A, B, C, D, and E) $[10,11]$. Resveratrol derived from yucca possess potent anti-inflammatory and antioxidant effects $[9,40]$. The extract or powder of yucca leaves or roots could exhibit strong antioxidant properties [5]. The same results were reported by Alagawany et al. [10], who found that the activity of SOD and GSH were quadratically improved in yucca (with 50, 100, or $150 \mathrm{mg} / \mathrm{kg}$ of yucca extract) supplemented groups. The concentration of MDA was decreased with yucca supplementation in comparison with a control group. 
Table 5. Effect of dietary yucca supplementation on some blood parameters of broiler chickens.

\begin{tabular}{|c|c|c|c|c|}
\hline \multirow{2}{*}{ Item } & \multicolumn{3}{|c|}{ Group $^{1}$} & \multirow{2}{*}{$p$-Value ${ }^{2}$} \\
\hline & G1 & G2 & G3 & \\
\hline \multicolumn{5}{|l|}{ At 21st day } \\
\hline $\operatorname{IgM}(\mathrm{mg} / 100 \mathrm{~mL})$ & $74.87 \pm 0.22$ & $77.68 \pm 0.87$ & $82.51 \pm 0.38$ & 0.810 \\
\hline $\operatorname{IgG}(\mathrm{mg} / 100 \mathrm{~mL})$ & $183.86 \pm 2.37$ & $183.01 \pm 1.89$ & $184.46 \pm 5.24$ & 0.992 \\
\hline $\mathrm{SOD}(\mathrm{mg} / \mathrm{dL})$ & $37.84 \pm 2.38^{b}$ & $40.16 \pm 1.5^{b}$ & $56.35 \pm 1.88^{a}$ & 0.001 \\
\hline CAT (mg/dL) & $24.88 \pm 1.74^{b}$ & $26.91 \pm 1.8^{b}$ & $32.20 \pm 0.84^{\mathrm{a}}$ & 0.016 \\
\hline MDA (mg/dL) & $62.83 \pm 2.61$ & $57.97 \pm 0.12$ & $57.70 \pm 1.17$ & 0.567 \\
\hline GSH (mg/dL) & $37.02 \pm 1.55$ & $41.2 \pm 1.47$ & $40.61 \pm 0.69$ & 0.613 \\
\hline $\operatorname{ALT}(\mathrm{U} / \mathrm{L})$ & $36.07 \pm 1.49$ & $34.84 \pm 2.11$ & $38.69 \pm 1.21$ & 0.941 \\
\hline Creatinine $(\mathrm{mg} / \mathrm{dL})$ & $0.47 \pm 0.04$ & $0.46 \pm 0.04$ & $0.47 \pm 0.01$ & 0.971 \\
\hline Albumin (g/dL) & $1.99 \pm 0.07$ & $2.06 \pm 0.08$ & $2.08 \pm 0.06$ & 0.732 \\
\hline Total protein $(\mathrm{g} / \mathrm{dL})$ & $5.3 \pm 0.07$ & $5.36 \pm 0.11$ & $5.21 \pm 0.09$ & 0.578 \\
\hline Globulin (g/dL) & $3.33 \pm 0.12$ & $3.36 \pm 0.19$ & $3.13 \pm 0.14$ & 0.623 \\
\hline TGS (mg/dL) & $169.6 \pm 16.21$ & $143.11 \pm 10.17$ & $180.62 \pm 17.41$ & 0.376 \\
\hline Cholesterol (mg/dL) & $247.06 \pm 9.29$ & $205.43 \pm 12.99$ & $254.12 \pm 8.58$ & 0.897 \\
\hline \multicolumn{5}{|l|}{ At 35th day } \\
\hline $\operatorname{IgM}(\mathrm{mg} / 100 \mathrm{~mL})$ & $83.72 \pm 2.26$ & $80.01 \pm 1.34$ & $80.73 \pm 1.57$ & 0.899 \\
\hline $\operatorname{IgG}(\mathrm{mg} / 100 \mathrm{~mL})$ & $201.36 \pm 4.63^{\mathrm{a}}$ & $201.84 \pm 4.79^{\mathrm{a}}$ & $80.73 \pm 1.57^{b}$ & 0.001 \\
\hline $\mathrm{SOD}(\mathrm{mg} / \mathrm{dL})$ & $48.02 \pm 2.84$ & $50.19 \pm 1.18$ & $50.52 \pm 0.68$ & 0.373 \\
\hline CAT (mg/dL) & $38.34 \pm 2.91^{c}$ & $52.52 \pm 0.98^{b}$ & $63.65 \pm 2.7^{a}$ & 0.001 \\
\hline $\operatorname{MDA}(\mathrm{mg} / \mathrm{dL})$ & $81.54 \pm 1.79^{a}$ & $68.04 \pm 2^{b}$ & $60.66 \pm 0.42^{c}$ & 0.001 \\
\hline GSH (mg/dL) & $53.05 \pm 2.65^{\mathrm{c}}$ & $72.14 \pm 1.67^{b}$ & $81.66 \pm 1.74^{\mathrm{a}}$ & 0.001 \\
\hline $\operatorname{ALT}(\mathrm{U} / \mathrm{L})$ & $45.78 \pm 2.04$ & $45.41 \pm 2.06$ & $42.56 \pm 2.69$ & 0.750 \\
\hline Creatinine (mg/dL) & $0.87 \pm 0.03$ & $0.84 \pm 0.03$ & $0.83 \pm 0.05$ & 0.836 \\
\hline Albumin (g/dL) & $2.13 \pm 0.06$ & $2.06 \pm 0.12$ & $2.13 \pm 0.08$ & 0.721 \\
\hline Total protein (g/dL) & $5.43 \pm 0.06$ & $5.56 \pm 0.11$ & $5.63 \pm 0.09$ & 0.597 \\
\hline Globulin (g/dL) & $3.24 \pm 0.06$ & $3.5 \pm 0.16$ & $3.5 \pm 0.12$ & 0.653 \\
\hline TGS (mg/dL) & $168.89 \pm 16.53$ & $182.76 \pm 9.05$ & $210.96 \pm 15.62$ & 0.456 \\
\hline Cholesterol (mg/dL) & $223.17 \pm 3.89^{b}$ & $254.53 \pm 7.49^{\mathrm{a}}$ & $224.44 \pm 12.73^{b}$ & 0.018 \\
\hline
\end{tabular}

${ }^{\mathrm{a}-\mathrm{c}}$ Means within the same row that carry different superscripts are significantly different at $p<0.05 .{ }^{1} \mathrm{G} 1$ : control without supplementation, G2: $0.5 \mathrm{~mL} / \mathrm{L}, 8 \mathrm{~h} /$ day drinking water and G3: $1 \mathrm{~mL} / \mathrm{L}, 8 \mathrm{~h} /$ day drinking water, Mean $\pm \mathrm{SE}$.

${ }^{2}$ Overall treatment $p$-value. IgM, immunoglobulin M; IgG, immunoglobulin G; SOD, superoxide dismutase; CAT, catalase; MDA, malondialdehyde; GSH, glutathione; ALT, alanine amino transferase; TGS, triglycerides.

\section{Conclusions}

Yucca appeared to decrease nitrogen excretion, thus improving litter quality and bird welfare, and consequently, improving the gut health and performance of broiler chickens. This study gives new evidence for the use of saponins as natural alternatives to antibiotics and growth promoters.

Author Contributions: Conceptualization, M.M.A., H.A.A., K.M.S. and M.A.A.-L.; Data curation, M.M.A., H.A.A., K.M.S. and M.A.A.-L.; Funding acquisition, S.I.O. and A.A.A.; Investigation, M.M.A., H.A.A., K.M.S. and M.A.A.-L.; Methodology, M.M.A., H.A.A., and K.M.S.; Resources, M.M.A., H.A.A., K.M.S., M.A.A.-L., S.I.O. and A.A.A.; Writing—original draft, M.A. and M.E.A.E.-H.; Writing—review \& editing, M.A.

Acknowledgments: This research was funded by the Deanship of Scientific Research, at Princess Nourah bint Abdulrahman University, through the Fast-track Research Funding Program.

Conflicts of Interest: The authors declare no conflict of interest.

\section{References}

1. Costa, A.; Ferrari, S.; Guarino, M. Yearly emission factors of ammonia and particulate matter from three laying-hen housing systems. Anim. Prod. Sci. 2012, 52, 1089-1098. [CrossRef]

2. Kristensen, H.H.; Burgess, L.R.; Demmers, T.G.M.; Wathes, C.M. The preferences of laying hens for different concentrations of atmospheric ammonia. Appl. Anim. Behav. Sci. 2000, 68, 307-318. [CrossRef] 
3. Kathirvelan, C.; Banupriya, S.; Patric Joshua, P.; Ramesh, J. Poultry house managements to reduce ammonia emission. Int. J. Sci. Environ. Technol. 2016, 5, 1669-1672.

4. Groot Koerkamp, P.W.G. Review on emissions of ammonia from housing systems for laying hens in relation to sources, processes, building design and manure handling. J. Agric. Eng. 1994, 59, 73-87. [CrossRef]

5. Alagawany, M.; Farag, M.R.; Dhama, K.; Abd El-Hack, M.E.; Tiwari, R.; Alam, G.M. Mechanisms and beneficial applications of resveratrol as feed additive in animal and poultry nutrition: A Review. Int. J. Pharmacol. 2015, 11, 213-221. [CrossRef]

6. Ashour, E.A.; Alagawany, M.; Reda, F.M.; Abd El-Hack, M.E. Effect of supplementation of Yucca schidigera to growing rabbits diets on growth performance, carcass characteristics, serum biochemistry and liver oxidative status. Asian J. Anim. Sci. Vet. Adv. 2014, 9, 732-742.

7. Saeed, M.; Arain, M.A.; Naveed, M.; Alagawany, M.; Abd El-Hack, M.E.; Bhutto, Z.A.; Marek, B.; Kakar, M.U.; Abdel-Latif, M.; Chao, S. Yucca schidigera can mitigate ammonia emissions from manure and promote poultry health and production. Environ. Sci. Pollut. Res. 2018, 25, 35027-35033. [CrossRef]

8. Ayasan, T.; Yurtseven, S.; Baylan, M.; Canogullari, S. The effects of dietary Yucca schidigera on egg yield parameters and egg shell quality of laying Japanese quails [Coturnix coturnix japonica]. Int. J. Poult. Sci. 2005, 4, 159-162.

9. Farag, M.R.; Alagawany, M.; Tufarelli, V. In vitro antioxidant activities of resveratrol, cinnamaldehyde and their synergistic effect against cyadox-induced cytotoxicity in rabbit erythrocytes. Drug Chem. Toxicol. 2016, 40, 196-205. [CrossRef]

10. Alagawany, M.; Abd El-Hack, M.E.; El-Kholy, M.S. Productive performance, egg quality, blood constituents, immune functions, and antioxidant parameters in laying hens fed diets with different levels of Yucca schidigera extract. Environ. Sci. Pollut. Res. 2016, 23, 6774-6782. [CrossRef]

11. Alagawany, M.; Abd El-Hack, M.E.; Farag, M.R.; Elnesr, S.S.; El-Kholy, M.S.; Saadeldin, I.M.; Swelum, A.A. Dietary supplementation of Yucca schidigera extract enhances productive and reproductive performances, blood profile, immune function, and antioxidant status in laying Japanese quails exposed to lead in the diet. Poult. Sci. 2018, 97, 3126-3137. [CrossRef]

12. Gupta, S. Inhibitory potential of yucca gloriosa 1. extract and isolated gloriosaol isomeric mixture on ovalbumin induced airway hyperresponsiveness in Balb/C mice. Clin. Pharmacol. Biopharm. 2014, 2. [CrossRef]

13. Vlckova, R.; Sopkova, D.; Andrejcakova, Z.; Valocky, I.; Kadasi, A.; Harrath, A.H.; Petrilla, V.; Sirotkin, A.V. Dietary supplementation of yucca (Yucca schidigera) affects ovine ovarian functions. Theriogenology 2017, 88, 158-165. [CrossRef] [PubMed]

14. Tenon, M.; Feuillere, N.; Roller, M.; Birtic, S. Rapid, costeffective and accurate quantification of Yucca schidigera Roezl. steroidal saponins using HPLC-ELSD method. Food Chem. 2017, 221, 1245-1252. [CrossRef] [PubMed]

15. Nazeer, M.S.; Pasha, T.N.; Shahid, A.; Ali, Z. Effect of Yucca saponin on urease activity and development of ascites in broiler chickens. Int. J. Poult. Sci. 2002, 16, 174-178.

16. Farag, R.M.; Alagawany, M.; Abd El-Hack, M.E.; El-Sayed, S.A.A.; Ahmed, S.Y.A.; Samak, D.H. Yucca schidigera extract modulates the lead-induced oxidative damage, nephropathy and altered inflammatory response and glucose homeostasis in Japanese quails. Ecotoxicol. Environ. Saf. 2018, 156, 311-321. [CrossRef]

17. Ebru, O.E.; Erdem, E.; Afsinya, N.U.; Torlak, E. Effect of Yucca schidigera spraying in different litter materials on some litter traits and breast burn of broilers at the fifth week of production. Kafkas Univ. Vet. Fak. Derg. 2013, 19, 749-753.

18. NRC. Nutrient Requirements of Poultry, 9th ed.; National Academy Press: Washington, DC, USA, 1994.

19. AOAC. Official Method of Analysis; Association of Official Analytical Chemist: Washington, DC, USA, 2000.

20. Mountzouris, K.C.; Tsirtsikos, P.; Kalamara, E.; Nitsch, S.; Schatzmayr, G.; Fegeros, K. Evaluation of the efficacy of a probiotic containing Lactobacillus, Bifidobacterium, Enterococcus, and Pediococcus strains in promoting broiler performance and modulating cecal microflora composition and metabolic activities. Poult. Sci. 2007, 86, 309-317. [CrossRef]

21. Lavanya, G.; Voravuthikunchai, S.P.; Towatana, N.H. Acetone extract from Rhodomyrtus tomentosa: A potent natural antioxidant. Evid. Based Complement. Altern. Med. 2012, 2012, 1-8. [CrossRef]

22. Manubolu, M.; Goodla, L.; Ravilla, S.; Thanasekaran, J.; Dutta, P.; Malmlöf, K.; Obulum, V.R. Protective effect of Actiniopteris radiata (Sw.) Link. against CCl4 induced oxidative stress in albino rats. J. Ethnopharmacol. 2014, 15, 744-752. [CrossRef] 
23. Goodla, L.; Manubolu, M.; Pathakoti, K.; Jayakumar, T.; Sheu, J.R.; Fraker, M.; Tchounwou, P.B.; Poondamalli, P.R. Protective effects of ammannia baccifera against CCl4-Induced oxidative stress in rats. Int. J. Environ. Res. Public Health 2019, 16, 1440. [CrossRef] [PubMed]

24. Bianchi, A.T.J.; Moonen-Leusen, H.W.M.; van der Heijden, P.J.; Bokhout, B.A. The use of a double antibody sandwich ELISA and monoclonal antibodies for the assessment of porcine IgM, IgG, and IgA concentrations. Vet. Immunol. Immunopathol. 1995, 44, 309-317. [CrossRef]

25. Fossati, P.; Prencipe, L. Serum triglycerides determined colorimetrically with an enzyme that produces hydrogen peroxide. Clin. Chem. 1982, 28, 2077-2080. [PubMed]

26. Stein, E.A. Quantitative enzymatic colorimetric determination of total cholesterol in serum or plasma. In Textbook of Clinical Chemistry; Tietz, N.W., Ed.; WB. Saunders: Philadelphia, PA, USA, 1986; pp. 879-886.

27. Cabuk, M.; Alcicek, A.; Bozkurt, M.; Akkan, S. Effect of Yucca schidigera and natural zeolite on broiler performance. Int. J. Poult. Sci. 2004, 3, 651-654.

28. Wang, J.P.; Kim, I.H. Effect of caprylic acid and Yucca schidigera extract on production performance, egg quality, blood characteristics, and excreta micro flora in laying hens. Br. Poult. Sci. 2011, 52, 711-717. [CrossRef]

29. Su, J.L.; Shi, B.L.; Zhang, P.F.; Sun, D.S.; Li, T.Y.; Yan, S.M. Effects of yucca extract on feed efficiency, immune and antioxidative functions in broilers. Braz. Arch. Biol. Technol. 2016, 59, e16150035. [CrossRef]

30. Sahoo, S.P.; Kaur, D.; Sethi, A.P.S.; Sharma, A.; Chandra, M. Evaluation of Yucca schidigera extract as feed additive on performance of broiler chicks in winter season. Vet. World 2015, 8, 556-560. [CrossRef]

31. Alfaro, D.M.; Silva, A.V.F.; Borges, S.A.; Maiorka, F.A.; Vargas, S.; Santin, E. Use of Yucca schidigera extract in broiler diets and its effects on performance results obtained with different coccidiosis control methods. J. Appl. Poult. Res. 2007, 16, 248-254. [CrossRef]

32. Choi, I.H.; Moore, P.A., Jr. Effect of Various Litter Amendments on Ammonia Volatilization and Nitrogen Content of Poultry Litter. J. Appl. Poult. Res. 2008, 17, 454-462. [CrossRef]

33. Johnson, N.L.; Quarles, C.L.; Fegerberg, D.J.; Caveny, D.D. Evaluation of yucca saponin on broiler performance and ammonia suppression. Poult. Sci. 1981, 60, 2289-2292. [CrossRef]

34. Miles, D.M.; Branton, S.L.; Lott, B.D. Atmospheric ammonia is detrimental to the performance of modern commercial broilers. Poult. Sci. 2014, 83, 1650-1654. [CrossRef] [PubMed]

35. Oelschlager, M.L.; Rasheed, M.S.A.; Smith, B.N.; Rincker, M.J.; Dilger, R.N. Effects of Yucca schidigera-derived saponin supplementation during a mixed Eimeria challenge in broilers. Poult. Sci. 2019, 98, 3212-3222. [CrossRef] [PubMed]

36. Liang, D.; Wang, B.; Song, S.; Wang, J.; Wang, L.; Wang, Q.; Ren, X.; Zhao, X. Analysis of genetic effects on a complete diallel cross test of Pinus koraiensis. Euphytica 2019, 215, 92. [CrossRef]

37. Geetha, V.; Chakravarthula, S.N. Chemical composition and anti-inflammatory activity of Boswellia ovalifoliolata essential oils from leaf and bark. J. For. Res. 2018, 29, 373-381. [CrossRef]

38. Alagawany, M.; Farag, M.R.; El-Kholy, M.S.; El-Sayed, S.A.A.; Dhama, K. Effect of resveratrol, cinnamaldehyde and their combinations on the antioxidant defense system and ATP release of rabbit erythrocytes: In vitro study. Asian J. Anim. Sci. Vet. Adv. 2016, 12,1-9. [CrossRef]

39. Cheeke, P. Applications of saponins as feed additives in poultry production. In Proceedings of the 20th Australian Poultry Science Symposium, Sydney, Australia, 3 December 2009; p. 50.

40. Chepete, H.J.; Xin, H.; Mendes, L.B.; Li, H.; Bailey, T.B. Ammonia emission and performance of laying hens as affected by different dosages of Yucca schidigera in the diet. J. Appl. Poult. Res. 2012, 21, 522-530. [CrossRef]

41. Hussain, I.; Ismail, M.A.; Cheeke, P.R. Effects of feeding Yucca schidigera extract in diets varying in crude protein and urea contents on growth performance and caecum and blood urea and ammonia concentration of rabbits. Anim. Feed Sci. Technol. 1996, 62, 121-129. [CrossRef]

42. Chrenková, M.; Chrastinová, L’; Poláčiková, M.; Formelová, Z.; Baláži, A.; Ondruška, L'; Sirotkin, A.; Chrenek, P. The effect of Yucca schidigera extract in diet of rabbits on nutrient digestibility and qualitative parameters in caecum. Slovak J. Anim. Sci. 2012, 45, 83-88.

(C) 2019 by the authors. Licensee MDPI, Basel, Switzerland. This article is an open access article distributed under the terms and conditions of the Creative Commons Attribution (CC BY) license (http://creativecommons.org/licenses/by/4.0/). 